\title{
Effect of Rice Root-Knot Nematode on Growth and Yield of Yellow Granex Onion
}

\author{
E. B. Gergon, Philippine Rice Research Institute, Muñoz, Nueva Ecija, Philippines; S. A. Miller, Department of \\ Plant Pathology, The Ohio State University, Wooster 44691; J. M. Halbrendt, Department of Plant Pathology, Penn \\ State University Fruit Research and Extension Center, Biglerville, PA 17307; and R. G. Davide, Department of \\ Plant Pathology, University of the Philippines Los Baños, College, Laguna 4031, Philippines
}

\begin{abstract}
Gergon, E. B., Miller, S. A., Halbrendt, J. M., and Davide, R. G. 2002. Effect of rice root-knot nematode on growth and yield of Yellow Granex onion. Plant Dis. 86:1339-1344.

Rice root-knot nematode, Meloidogyne graminicola, infects all commercially grown onion cultivars in rice-onion cropping systems in the Philippines, but its economic importance has not been established. The effects of different preplant population levels (Pi) of M. graminicola on Yellow Granex onion in pots and of different percentages of galled roots in a naturally infested field were evaluated. Leaf weight and root length of 'Yellow Granex 429' seedlings decreased with increasing Pi, while low Pi mildly stimulated plant height at the vegetative growth stage. Age of transplant and Pi influenced growth and yield of onion at maturity. Onion yield and root and leaf weights decreased as the age of the transplants increased. Growth and yield decreased with increased Pi. Bulb weight was reduced by 7 to $82 \%$ and diameter by 10 to $62 \%$ when plants were inoculated with 50 to 10,000 second-stage juveniles. Onion bulbs from the field were reduced by 16,32 , and $35 \%$ in weight and by 6,17 , and $18 \%$ in diameter when the percentage of roots galled was 10, 50, and $100 \%$, respectively. Management of M. graminicola populations at the start of the growing season must be part of onion culture in rice-onion systems to reduce onion yield losses and to prevent economic loss.
\end{abstract}

Several species of Meloidogyne cause damage to onion (Allium cepa L.) (8). The northern root-knot nematode, M. hapla, retards growth of onion by up to $60 \%$ under greenhouse conditions (9) and yield losses up to $64 \%$ have been recorded at high nematode density (12). In the Philippines, where onion is usually grown after rice, root-knot disease of onion (Fig. 1) mainly is caused by the rice root-knot nematode, M. graminicola Golden \& Birchfield (4).

M. graminicola causes economic losses in rice that vary depending on the agroecosystem in which the rice crop is grown. Losses of $20 \%$ have been documented for rice cultivars IR 29 and IR 74 under intermittent flooding (18), of $30 \%$ in semideepwater rice (15), and of $70 \%$ under saturated conditions when the nematode infects young susceptible seedlings at transplanting (16). Jairajpuri and Baqri (7) reported grain yield losses from 16 to $32 \%$. The nematode has adapted to its environ-

Corresponding author: S. A. Miller E-mail: miller.769@osu.edu

This research was supported by Integrated Pest Management Collaborative Research Program (IPM CRSP) funded by USAID Global Bureau Grant No. LAG G-00-93-00053-00.

Accepted for publication 5 August 2002.

Publication no. D-2002-1015-01R

(c) 2002 The American Phytopathological Society ment in that its egg masses can remain viable in waterlogged soil for 14 months or more (17). Once the soil dries, the second stage juveniles become active and enter the roots of the succeeding susceptible crop. The continuous rice-onion cropping practiced in the Philippines province of Nueva Ecija makes this nematode a potentially important pest. To date, all cultivars of bulb onion grown commercially in the Philippines are susceptible to this pest (4). This includes the Yellow Granex types that are raised for export and represent an important source of income for Philippine farmers in this region. The effect of $M$. graminicola on growth and yield of onion has not been established, but such information is necessary to develop nematode management strategies. The objectives of this study were to assess and quantify the effects of $M$. graminicola on the growth and yield of Yellow Granex bulb onion and to determine the relationships among plant age at transplanting, growth and yield parameters, and initial nematode density surrounding the roots of onion plants.

\section{MATERIALS AND METHODS}

Inoculum production. The identity of the species causing root-knot disease of onion was verified through quantitative measurements of physical attributes of second-stage juveniles (J2), mature males, and females from a population established from a single egg mass on onion. Cross inoculations of onion and rice with $M$. graminicola from the culture collection of the International Rice Research Institute, Los Baños, Laguna confirmed the identity of the causal agent as M. graminicola (E. B. Gergon, unpublished).

Inoculum of $M$. graminicola was obtained from infected Yellow Granex onion roots collected from San Jose City, Nueva Ecija and multiplied on the rice cultivar

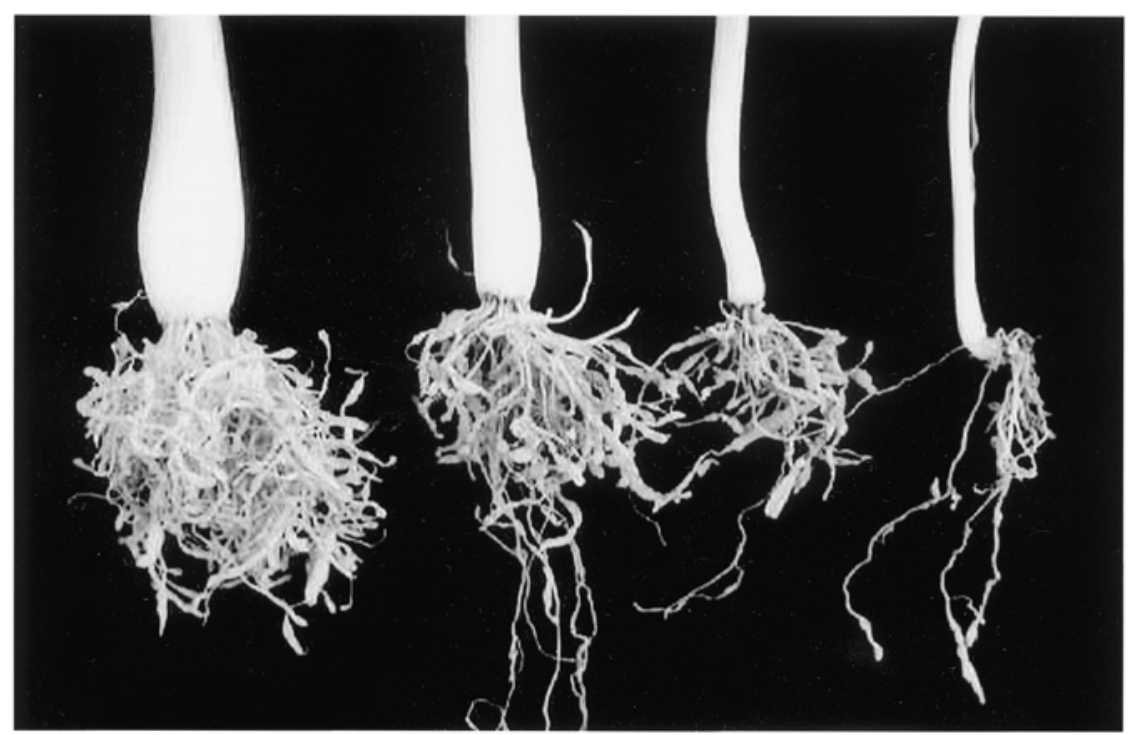

Fig. 1. 'Yellow Granex 429' onion with underdeveloped bulbs and short, galled roots after inoculation with root-knot nematode, Meloidogyne graminicola. 
UPLRi-5. To extract active $\mathrm{J} 2$, galled roots were cut into $5-\mathrm{cm}$-long pieces, placed in a misting chamber, and sprayed intermittently with a fine mist of water for $1 \mathrm{~min}$

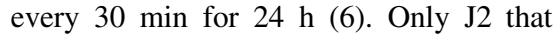
emerged after $24 \mathrm{~h}$ were used as inoculum.

Effect of inoculum density on onion seedling growth. Seedlings of the hybrid
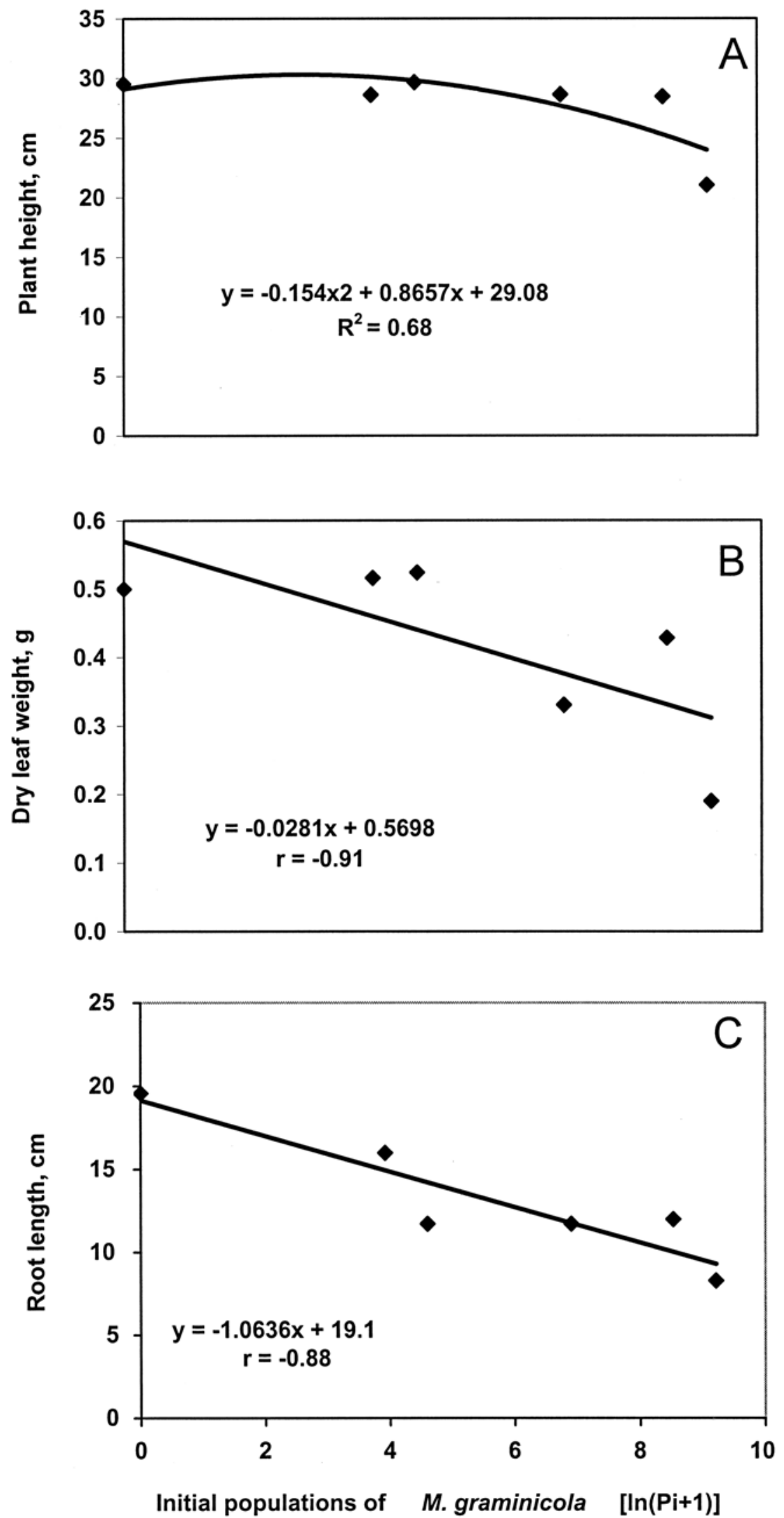

Fig. 2. Effect of initial population density (Pi) of Meloidogyne graminicola on A, plant height, B, leaf dry weight, and C, root length of 'Yellow Granex 429' onion. onion 'Yellow Granex 429' (Asgrow Seed Company, Kalamazoo, MI) were grown in sterile soil. Ninety 15 -day-old seedlings of uniform height were transplanted individually in 30-cm-diameter clay pots filled with $12 \mathrm{~kg}$ of a sterile sandy loam soil:carbonized rice hull $(2: 1)$ mixture, which simulates the growing medium used by onion farmers in San Jose City. The seedlings were inoculated with initial population densities ( $\mathrm{Pi}$ ) of $0,50,100$, 1,000, 5,000, and 10,000 M. graminicola $\mathrm{J} 2$ per plant 1 day after transplanting. Suspensions of $M$. graminicola were introduced into two 5-cm-deep holes made 1 $\mathrm{cm}$ from the base of the seedlings and near the root zone. All treatments were replicated five times and arranged in a randomized complete block design with $10-\mathrm{cm}$ spacing between pots. Onion plants were maintained in the greenhouse at 25 to $34^{\circ} \mathrm{C}$, watered every day to field capacity, and fertilized with N-P-K at 120-240-120 $\mathrm{kg} / \mathrm{ha}$. $\mathrm{N}$ was applied in two equal parts 1 and 4 weeks after transplanting, whereas $P$ and $\mathrm{K}$ were applied 1 week after transplanting. Recommended insecticides were applied when necessary to control foliar insects. Thirty plants were harvested 45 , 55 , or 70 days after sowing, and plant height, leaf fresh weight, and percentage of galled roots were recorded for each plant. Root length and root fresh weight were measured after rinsing each root system and blotting it dry with tissue paper. The experiment was conducted twice.

Effect of inoculum density and transplant age on onion growth and yield. 'Yellow Granex 429' seedlings 15, 45, or 55 days old (one per pot) were transplanted into 30-cm-diameter clay pots containing $12 \mathrm{~kg}$ of a sterile sandy loam soil: carbonized rice hull $(2: 1)$ mixture on the same day. One day after transplanting, $M$. graminicola $\mathrm{J} 2$ at $\mathrm{Pi}$ of $0,50,100,1,000$, 5,000 , or 10,000 per plant were introduced into two 5 -cm-deep holes made $1 \mathrm{~cm}$ from the base of healthy plants and near the root zone. All treatments were replicated five times with five plants per replicate, arranged in a randomized complete block design, and maintained in the greenhouse as described previously. After 120 days when the neck tissues had softened, the plants were carefully uprooted and soil adhering to the root system was removed using strong water pressure. After washing the roots, plant height from the tallest leaf to the base of the bulb, root length from the base of the bulb to the tip of the longest root, root fresh weight, bulb fresh weight and diameter, leaf fresh weight, leaf dry weight, percentage of galled roots, and the number of $\mathrm{J} 2$ per $3 \mathrm{~g}$ of roots were recorded. Leaf dry weight was measured after oven-drying the leaves at $50^{\circ} \mathrm{C}$ for 5 days. M. graminicola $\mathrm{J} 2$ were extracted by cutting roots into 5-cm-long pieces and spraying them with fine mist of water for 1 min every $30 \mathrm{~min}$ for 5 days in a mist 
chamber. The experiment was conducted twice.

Field evaluation. Fifty-day-old 'Yellow Granex 429' seedlings were transplanted into a farmer's field infested with $M$. graminicola. The field was a sandy loam soil $(54.45 \%$ sand, $34.83 \%$ silt, and $10.72 \%$ clay), $\mathrm{pH} 5.0$, located in San Jose City, Nueva Ecija. Plant density, irrigation, and weed control were uniform throughout the field. The plants were transplanted in January and harvested in April when they were 120 days old. Four hundred plants were collected from the field following a zigzag pattern. Each plant was carefully uprooted with the rhizosphere soil and placed in a plastic bag. Soil was washed from each root system and the top of each plant was removed. The roots were examined and root systems were sorted based on the percentage of root surface galled (no galls, 1 to $10 \%, 11$ to $30 \%, 31$ to $50 \%$, or 51 to $100 \%)$. The roots of 48 plants each with $0,10,50$, or $100 \%$ galling were cut into 5-cm-long pieces and mixed, and 3-g root samples were taken. J2 were extracted from the roots by misting (6). Bulb diameter was measured using a digital caliper and the weight of each bulb was recorded.

Statistical analyses. Plant response among inoculum levels and seedling ages recorded in greenhouse studies and the percentage of roots galled and yield parameters from the field were subjected to analysis of variance, regression, and correlation analysis. The appropriate relationship to fit the mean data was determined by partitioning of the treatment sum of squares into orthogonal polynomials. Nematode population data were transformed by $\log 10$ before analysis. Data from repeated experiments were averaged.

\section{RESULTS}

Effect of inoculum density on seedling growth. Age of the plants $(P<0.01)$ and inoculum density of $M$. graminicola $(P<$ $0.01)$ significantly affected growth of bulb onion 'Yellow Granex 429'. The interaction between these two factors on onion growth and yield parameters was not significant. Age of onion plants at harvest was positively correlated with plant height $(r=$ $0.81)$, fresh top weight $(r=0.92)$, root weight $(r=0.85)$, and root length $(r=$ 0.63). Initial inoculum densities of $M$. graminicola affected plant height, leaf dry weight, and root length, but did not affect root weight of onion bulbs (Fig. 2). The relationship of $\mathrm{Pi}(\ln [\mathrm{Pi}+1])$ to seedling height $\left(R^{2}=0.68\right)$ was described by a quadratic equation. Based on the equation, the average plant height reached a maximum at $\ln (\mathrm{Pi}+1)=2.8(\mathrm{Pi}<50)$ and then decreased. Leaf dry weight and root length were negatively correlated $(r=-0.91$ and -0.88 , respectively) with population density of $M$. graminicola. Regression analysis indicated that for one $\ln (\mathrm{Pi}+1)$ increase in initial nematode density, there was a corresponding reduction of $0.03 \mathrm{~g}$ in dry leaf weight and of $2.0 \mathrm{~cm}$ in root length per root system. The number of $\mathrm{J} 2$ in the roots per plant and the percentage of galled roots were not influenced by plant age, but were significantly correlated with initial inoculum density ( $r=0.77, P<0.01$ ). The percentage of galled roots was positively correlated with $\ln (\mathrm{Pi}+1)\left(R^{2}=0.890\right)$. In these experiments, initial nematode densities of $50 \mathrm{~J} 2 /$ plant were sufficient to cause root-knot disease.

Effect of transplant age and inoculum density on onion growth and yield. The interaction between age of transplant and $\mathrm{Pi}$ on growth and yield parameters of 'Yellow Granex 429' at maturity was not significant. The age of onion seedlings at transplanting significantly $(P<0.01)$ influenced bulb diameter and weight, leaf dry weight, and root fresh weight, but did not affect plant height and root length (Fig. 3). There was a linear relationship between
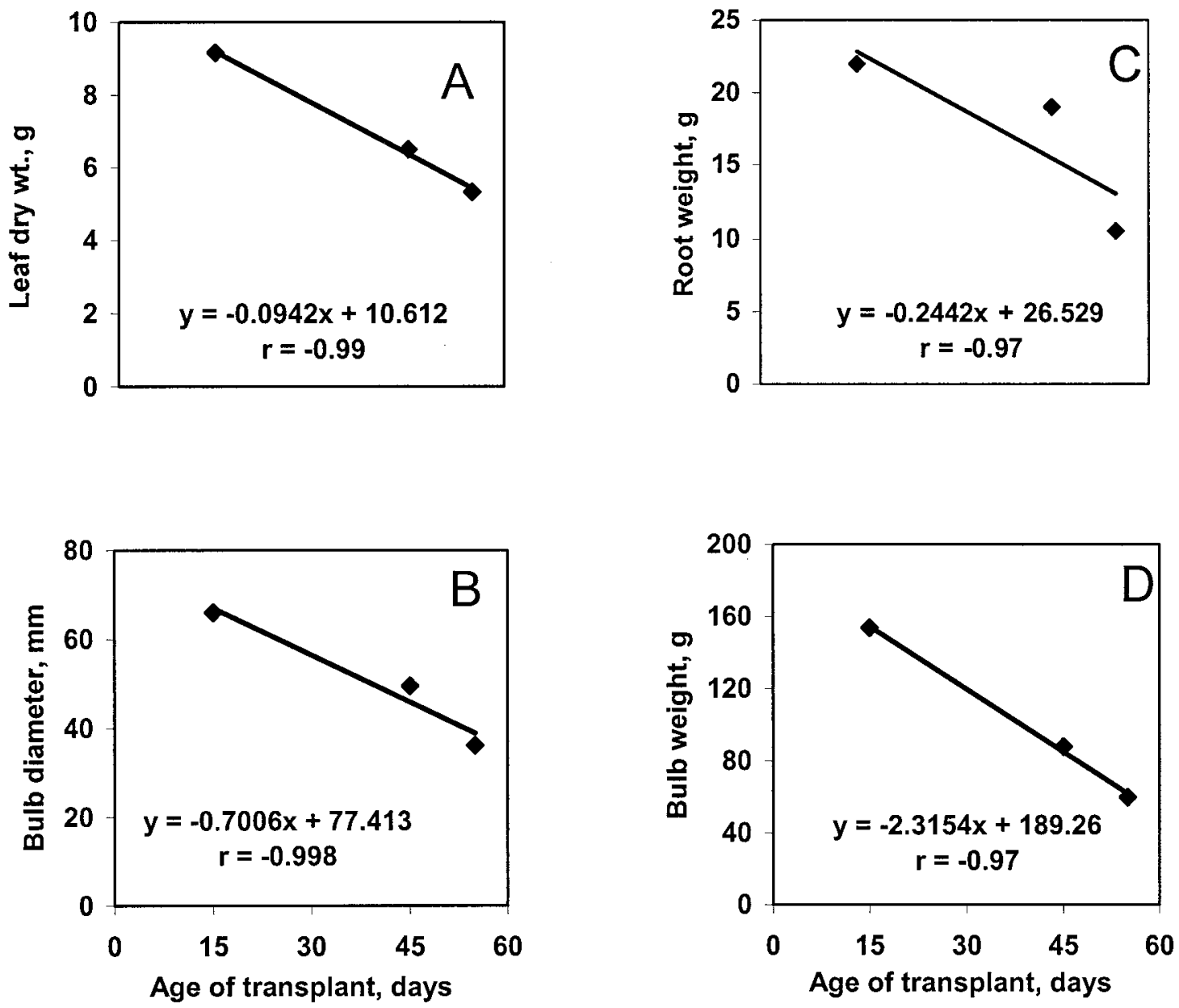

Fig. 3. Effect of age of seedlings at transplanting on A, leaf dry weight, B, bulb diameter, C, root weight, and D, bulb weight of 'Yellow Granex 429' onion. 
age of transplants and weight and diameter of bulbs, and weights of roots and leaves at harvest. As the age of the transplants increased, bulb weight and diameter and root and leaf weights decreased.

Inoculum densities of $M$. graminicola at the start of the growing season negatively affected growth and yield variables of 'Yellow Granex 429' at maturity. Growth and yield of onion bulbs decreased as initial population density $(\ln (\mathrm{Pi}+1])$ of $M$. graminicola increased (Fig. 4). Plant height $(r=-0.95)$, leaf dry weight $(r=$ $-0.91)$, root weight $(r=-0.99)$, and root length $(r=-0.97)$ were negatively and linearly correlated with $\mathrm{Pi}$. The regression analysis estimated an average decrease of
$1.4 \mathrm{~cm}$ in plant height, $0.8 \mathrm{~g}$ in leaf dry weight, $2.3 \mathrm{~g}$ in root weight, and $1.4 \mathrm{~cm}$ in root length for every one unit increase in $\ln (\mathrm{Pi}+1)$. The relationship between $\mathrm{Pi}$ $(\ln [\mathrm{Pi}+1])$ and yield of bulb onion was described by a negative linear regression (bulb diameter, $r=-0.96$; bulb weight, $r=$ -0.94 ; Fig. 4). For every one unit increase in $\ln (\mathrm{Pi}+1)$, the estimated average reduction in onion bulb weight was $11 \mathrm{~g}$, while bulb diameter was reduced $3.6 \mathrm{~mm}$. Based on the estimated mean bulb weight and diameter with no infection, the average bulb weight was reduced by $7,28,37,57$, and $82 \%$ when plants were inoculated with $50,100,1,000,5,000$, and $10,000 \mathrm{~J} 2$, respectively. The corresponding reduction in average bulb diameter was 10, 24, 28, 39, and $62 \%$. Bulb weight was positively correlated with bulb diameter $(r=0.93)$.

The age of transplant did not influence the final population densities of $M$. graminicola in the roots and percentage of galled roots. Final $\mathrm{J} 2$ per root system $(r=$ $0.93)$ and percent root galling $(r=0.83)$ were positively correlated with initial nematode density.

Yield loss in field-grown onion. $M$. graminicola reduced yield of Yellow Granex onion under field conditions, although the reduction in bulb development was less than that observed in greenhouse studies (Fig. 5). In the absence of nematodes, the estimated mean bulb weight (199 g) and
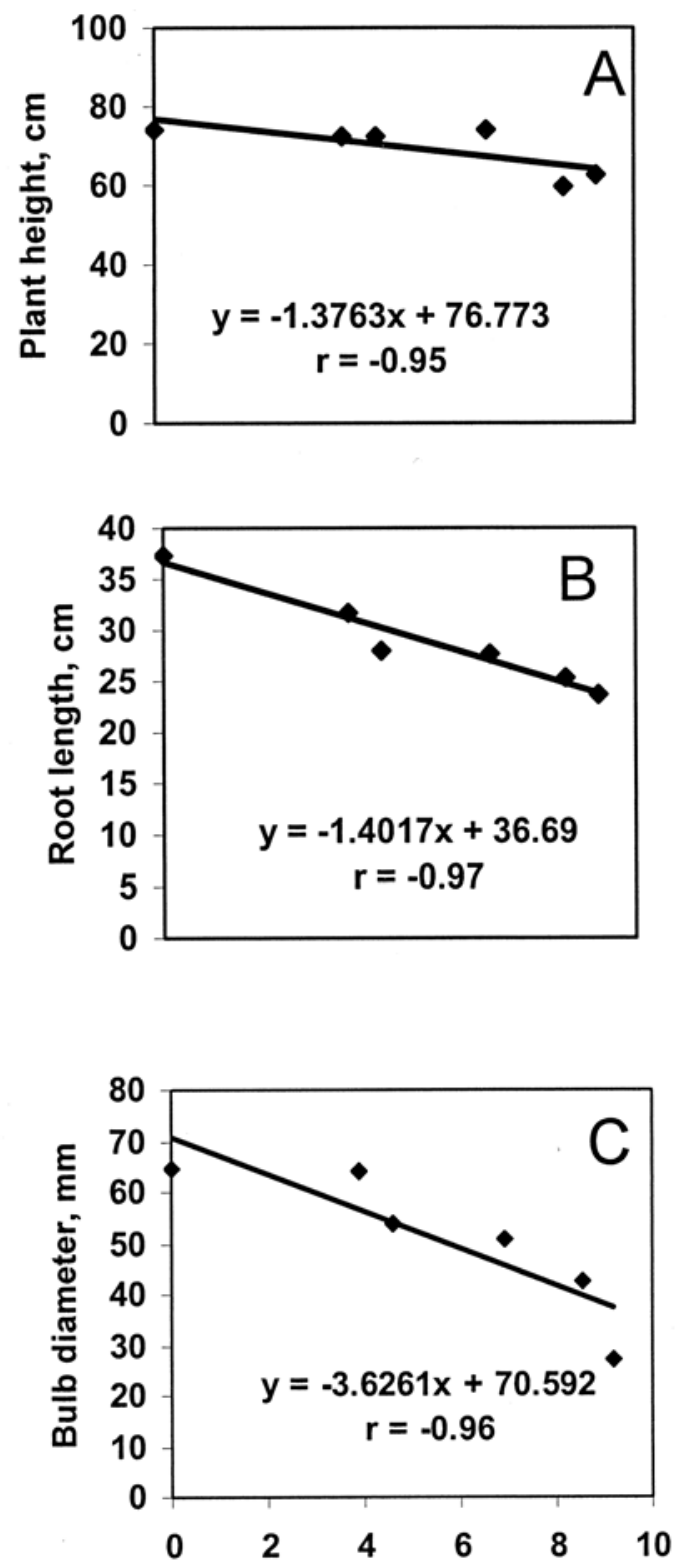

Initial populations of $M$. graminicola
\[ [\ln (\mathrm{Pi}+1)] \]
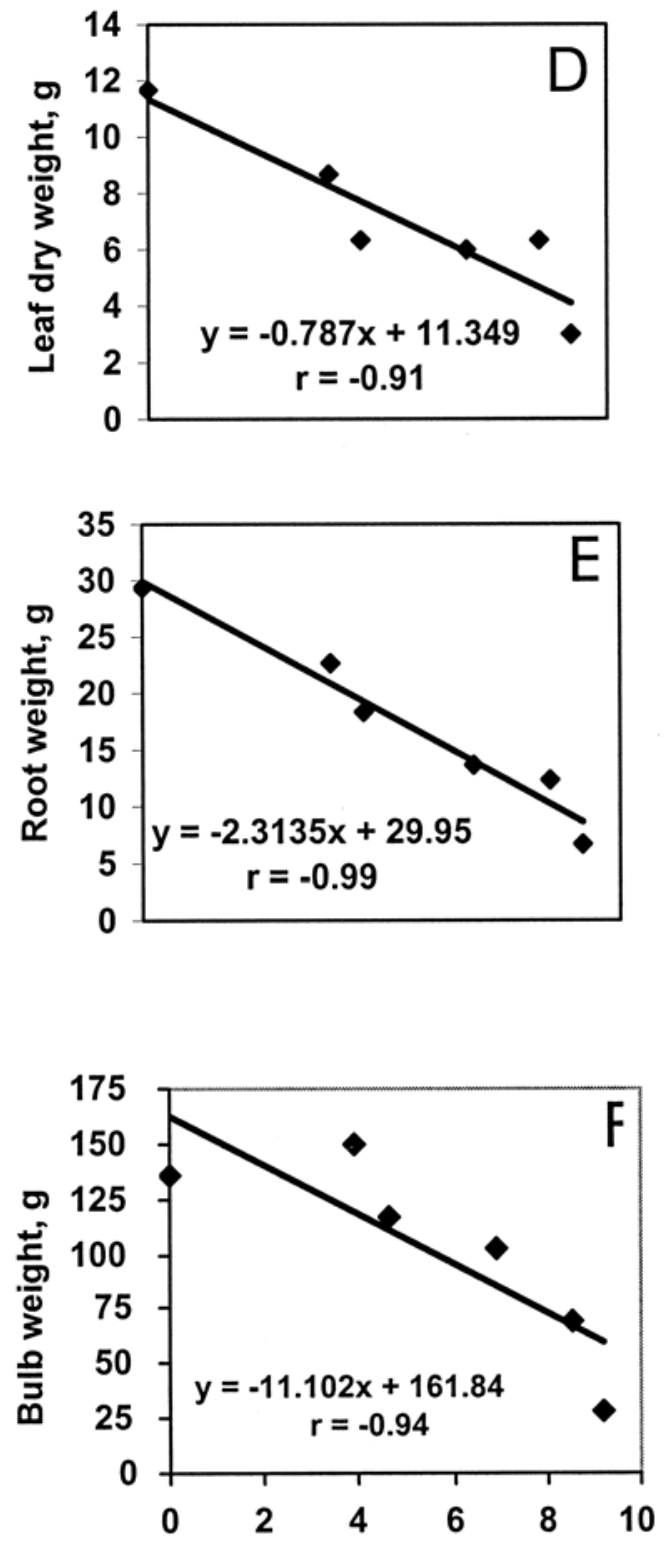

Initial populations of $M$. graminicola
\[ [\ln (\mathrm{Pi}+1)] \]

Fig. 4. Effect of initial population density (Pi) of Meloidogyne graminicola on A, plant height, B, root length, C, bulb diameter, D, leaf dry weight, E, root weight, and F, bulb weight of 'Yellow Granex 429' onion at harvest. 
diameter $(60 \mathrm{~mm})$ of field-grown Yellow Granex onion were lower than the estimated bulb weight (162 g) and diameter $(71 \mathrm{~mm})$ of greenhouse-grown onion. Bulb weight $(r=-0.94)$ and diameter $(r=-0.98)$ of onions harvested from a naturally infested field were negatively linearly correlated with the percentage of root galling (Fig. 5). Regression analysis of the percentage of root galling against bulb weight and diameter from field-grown onion also indicated lower estimates of reduction for both parameters in the field than those obtained in the greenhouse. Based on the estimated mean bulb weight and diameter with no infection, the average losses in bulb weights were 16,32 , and $35 \%$ and reduction in bulb diameter was 6,17 , and $18 \%$ when root galling was 10,50 , and $100 \%$, respectively.

\section{DISCUSSION}

The rice root-knot nematode significantly reduced growth and yield of onion 'Yellow Granex 429'. Thirty days after inoculation of 15-day-old seedlings, reduction in plant height and galls in the roots were evident. $M$. graminicola $\mathrm{J} 2$ have been observed in 'Yellow Granex 429' onion near the root tips 2 days after inoculation, developing into third- and fourth-stage larvae in 6 days, and completing the life cycle in less than 20 days (E. B. Gergon, unpublished). It is a common practice for farmers in the Philippines to purchase onion seedlings from off-farm sources; thus, seedlings produced in nematode-infested seedbeds may have a significant role in dissemination of the pathogen throughout onion-growing regions.

When 50 infective juveniles were introduced around young seedlings soon after transplanting, M. graminicola reduced leaf weight and root length in plants less than 50 days old (vegetative stage). The quadratic relationship between plant height and $\mathrm{Pi}$ at the vegetative stage indicated a slight increase in plant height at low inoculum levels, which suggests that low population levels of $M$. graminicola stimulated the growth of Yellow Granex onion. Mild stimulation of plant growth at low initial nematode densities has been reported in various vegetables by M. hapla (13), in pepper by $M$. javanica (10), and in rice under upland conditions by $M$. graminicola (16). Growth improvement has been attributed to the production of certain plant growth regulators in response to nematode invasion (18).

Growth and yield of onion also were influenced by the age of transplants. As the age of the transplant increased, bulb diameter and weight at harvest decreased across all nematode inoculum levels. Thus, there is apparently no benefit in transplanting older, larger seedlings, whether in the presence or absence of root-knot nematode.

Root length of onion was most dramatically affected by $M$. graminicola. This is particularly important in onion because root length per unit volume of soil is low compared with other crop species (3). Reduction in root length was likely a result of nematode feeding on giant cells, causing root growth to stop and tips to swell (11). This shortening of the roots affects the growth and development of the onion plant by limiting its ability to extract water and nutrients from the soil, eventually resulting in stunting and smaller bulbs. M. graminicola also causes stunting in rice $(1,14,16)$. Stunted rice plants have reduced leaf weight or top weight $(1,16,18)$, which was also observed in infected onion in this experiment. Root weight of onion, however, was not affected by the pathogen at early growth stages. The presence of root galls may have compensated for the reduced weight of healthy roots. This likely explains the insignificant relationship between root weight and inoculum density at this growth stage.
Reduction in yield of 'Yellow Granex $429^{\prime}$ with an initial nematode inoculum density of $50 \mathrm{~J} 2$ at transplanting indicates that onion plants are highly susceptible to root-knot nematode infection. Yield reduction also was evident in Yellow Granex onion bulbs produced in a field naturally infested by $M$. graminicola, where bulb diameter and weight decreased with increased root galling. The average decrease in diameter due to root-knot infection, however, was lower in the field than in pots in the greenhouse, which could be attributed to differences in soil moisture and other environmental conditions surrounding the plants. In the field, soil moisture is regulated and the plants may have acquired some tolerance by producing deeper roots. In addition, presowing population densities of $M$. graminicola in the field are generally lower than in the greenhouse because of land preparation that includes plowing two to three times
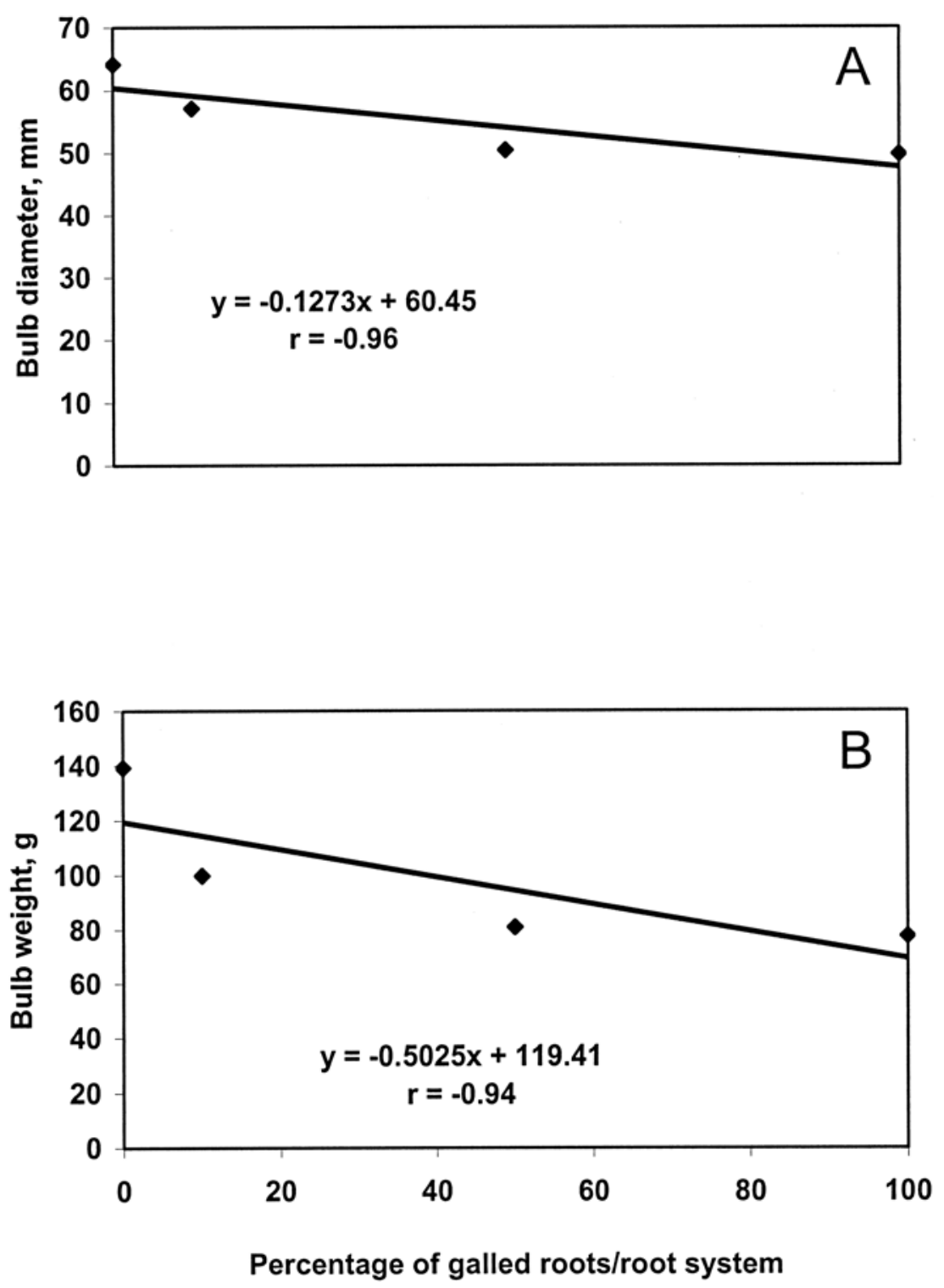

Fig. 5. Comparison of the percentage of root galling caused by Meloidogyne graminicola in a naturally infested field with A, bulb diameter and B, weight of 'Yellow Granex 429' onion at harvest. 
at the start of onion culture (5). A different community of biota also may be present in the field, which could affect the nematode population densities in the roots.

The number of $\mathrm{J} 2$ in the roots at harvest was very low and not significantly correlated with initial nematode densities (data not shown). Therefore, nematode population in onion roots at harvest was not used as a variable in these analyses. Preplant nematode density is considered a more appropriate descriptor in determining qualitative relationships between crop losses and nematode infection $(2,15)$. Infection of onion by $M$. graminicola also may be dependent on inoculum potential of the population and the environmental conditions (18). Soil population densities of M. graminicola at harvest also tend to be variable and may not be highly correlated with suppression of plant growth. Barker et al. (2) similarly observed poor correlation between final nematode density of $M$. hapla and $M$. incognita in the soil and growth of tomato.

Production of locally consumed and export onion in the Philippines can provide significant income to farmers with limited landholdings. Methods for management of root-knot nematode must be developed and integrated into onion culture in order to minimize losses in yield and quality. This is particularly important for Yellow Granex onion, because export value is highly dependent on bulb size.

\section{ACKNOWLEDGMENTS}

We thank A. Dorrance, S. Nethi, and P. Grewal, Ohio State University, for critically reviewing the manuscript.

\section{LITERATURE CITED}

1. Babatola, J. O. 1984. Rice nematode problems in Nigeria: Their occurrence, distribution, and pathogenesis. Trop. Pest Manage. 30:256-265.

2. Barker, K. R., Shoemaker, P. B., and Nelson, L. A. 1976. Relationships of initial population densities of Meloidogyne incognita and $M$. hapla to yield of tomato. J. Nematol. 8:232239.

3. Brewster, J. L. 1994. Onions and Other Vegetable Alliums. CAB International, Wallingford, Oxon, UK.

4. Gergon, E, B., Miller, S. A., and Davide, R. G. 2001. Root-knot disease of onion caused by the rice root-knot nematode Meloidogyne graminicola: Occurrence, pathogenicity, and varietal resistance. Philipp. Agric. Sci. 84:43-50.

5. Gergon, E, B., Miller, S. A., Davide, R. G., Opina, O. S., and Obien, S. R. 2001. Evaluation of cultural practices (surface burning, deep ploughing, organic amendments) for management of rice root-knot nematode in rice-onion cropping system and their effect on onion (Allium cepa L.) yield. Int. J. Pest Manage. 47:265-272.

6. Hooper, D. J. 1986. Extraction of nematodes from plant material. Pages 51-58 in: Laboratory Methods for Work with Plant and Soil Nematodes. Southey, J. J., ed. Reference Book 402, Ministry of Agriculture, Fisheries and Food, Her Majesty's Stationery Office. London, UK.

7. Jairajpuri, M. S., and Baqri, Q. H. 1991. Nematode pests of rice. Oxford and IBH Publishing Co. New Delhi.

8. Johnson, A. W., and Roberts, P. A. 1996. Diseases caused by nematodes. In: Compendium of Onion and Garlic Diseases. H. F.
Schwartz and S. K. Mohan, eds. American Phytopathological Society Press. St. Paul, MN.

9. MacGuidwin, A. E., Bird, G. W., Hayne, D. L., and Gage, S. H.. 1987. Pathogenicity and population dynamics of Meloidogyne hapla associated with Allium cepa. Plant Dis. 71:446-449.

10. Madamba, C. P., Sasser, J. N., and Nelson, L. A. 1965. Some characteristics of the effects of Meloidogyne spp. on unstable host crops. N. C. Agric. Exp. Stn. Tech. Bull. 169:1-34.

11. Manser, P. D. 1968. Meloidogyne graminicola, a cause of root-knot of rice. FAO Plant Prot. Bull. 16:11.

12. Olthof, T. H. A., and Potter, J. W. 1972. Relating nematode populations to crop losses. Can.-Agric. 17:18-19.

13. Olthof, T. H. A., and Potter, J. W. 1972. Relationship between population densities of Meloidogyne hapla and crop losses in summer maturing vegetables in Ontario. Phytopathology 62:691-986.

14. Plowright, R. A., and Bridge, J. 1990. Effect of Meloidogyne graminicola (Nematoda) on the establishment, growth and yield of rice cv. IR 36. Nematologica 36:81-89.

15. Prasad, J. S., Panwar, M. S., and Rao, Y. S. 1985. Occurrence of root-knot nematode Meloidogyne graminicola in semi-deepwater rice. Curr. Sci. 54(8):387-388.

16. Prot, J.C., Villanueva, L. M., and Gergon, E. B. 1994. The potential of increased nitrogen supply to mitigate growth and yield reduction of upland rice cultivar UPL Ri-5 caused by Meloidogyne graminicola. Fundam. Appl. Nematol. 17:445-454.

17. Roy, A. K. 1982. Survival of Meloidogyne graminicola eggs under different moisture conditions in vitro. Nematol. Mediterr. 10:221-222.

18. Tandingan, I. C., Prot, J.-C., and Davide, R. G. 1996. Influence of water management on tolerance of rice cultivars for Meloidogyne graminicola. Fundam. Appl. Nematol. 19:189-192. 